\title{
SEARCHING FOR NEW-TYPE ANTIFUNGAL DRUGS (AN OUTLINE FOR POSSIBLE NEW STRATEGIES)*
}

\author{
ISTVÁN PÓCSI ${ }^{1}$, LÁSZLÓ SÁMI ${ }^{1}$, ÉVA LEITER $^{1}$, LÁSZLÓ MAJOROS ${ }^{2}$, BÉlA SZABÓ ${ }^{2}$, \\ TAMÁS EMRI ${ }^{1}$ AND TÜNDE PUSZTAHELYI ${ }^{1}$ \\ ${ }^{1}$ Department of Microbiology and Biotechnology, Faculty of Sciences, University of Debrecen, \\ P.O. Box 63, H-4010 Debrecen, Hungary \\ ${ }^{2}$ Department of Microbiology, Faculty of Medicine, Medical and Health Center, University of \\ Debrecen, P.O. Box 17, H-4012 Debrecen, Hungary
}

(Received: March 26, 2001; accepted: April 5, 2001)

\begin{abstract}
New approaches for treatment of invasive fungal infections are necessary to cope with emerging resistant fungal pathogens of humans. In this paper, three different strategies are presented and evaluated to find new-type antifungal drugs and their targets. While experimental data obtained with potent chitinase inhibitors, e.g. allosamidin, and small-size antifungal proteins of fungal origin are encouraging more efforts are needed to verify and exploit the possible involvement of intracellular thiols, e.g. glutathione, and their metabolic enzymes in the pathogenesis of mycoses caused by dimorphic fungi. Chitinase inhibitors seem to hinder the cell separation of yeasts and the fragmentation of filamentous fungi quite effectively and, hence, they may be implicated in future therapies of systemic mycoses. In addition, small-size antifungal proteins possessing a broad inhibition spectrum may also provide us with promising new agents for the treatment of different kinds of (e.g. cutaneous) fungal infections.
\end{abstract}

Keyword: antifungal chemotherapy

\section{Introduction}

The incidence of invasive fungal infections rises steadily in humans starting from the 70s [1]. Patients receiving immunosuppressive therapies, using broad-

* This paper was written to commemorate to the fiftieth anniversary of the foundation of the Hungarian Society for Microbiology. 
spectrum antibacterial medicines for prolonged periods of time or suffering of immunosuppressive viral infections such as AIDS are especially predisposed to different kinds of mycoses. The number of nosocomial infections is also increasing sharply due to, for example, the common use of indwelling intravenous devices [1]. Recently used antifungal agents include ergosterol biosynthesis inhibitors, polyenes and 5-fluorocytosine $[1,2]$ but new targets and drug delivery systems are considered for antifungal therapy [3]. The development of new, safer and more effective antifungal drugs is stimulated by the undesirable side-effects of currently available medicines as well as the emergence of new pathogenic species possessing intrinsic primary resistance and common pathogens rapidly developing secondary resistance to these agents $[2,4]$. It is worth noting the threatening emergence of naturally resistant or even polyresistant non-albicans Candida species, e.g. Candida krusei in cancer patients [4] and during antifungal therapy [5]. In this paper, we outline the efforts we made in the last couple of years to find novel antifungal agents and define new targets for future antifungal drug research.

\section{Chitinolytic enzymes}

Compounds active against fungal cell wall biosynthetic enzymes including chitin synthetases and glucan synthetases are regarded as potential and promising targets for antifungal agents including nikkomycins and echinocandins [1]. Surprisingly, the endogenous cell wall degrading enzymes of these organisms, to which versatile and important nutritional, morphological and physiological functions are attributed [6,7], attracted much less attention until now. For example, all chitincontaining fungi studied thus far have been shown to produce chitinases that take part in swelling and germination of spores, branching and apical extension of growing hyphae, tailoring chitin microfibrils in rigidifying wall, cell separation of yeasts as well as age-related fragmentation and autolysis of hyphae [6-10]. Obviously, these important chitinolytic enzymes could be suitable targets for antifungal drug design in addition to cell wall biosynthetic enzymes.

We have already had some encouraging in vivo enzyme inhibition data in our hands concerning fungal chitinases. For example, the pseudotrisaccharide chitinase inhibitor allosamidin (Fig. 1) hindered effectively the cell separation of the yeasts Saccharomyces cerevisiae [11, 12] and Candida albicans [6], and the germination of some fungal spores was also found to be allosamidin-sensitive $[6,7,13]$. 


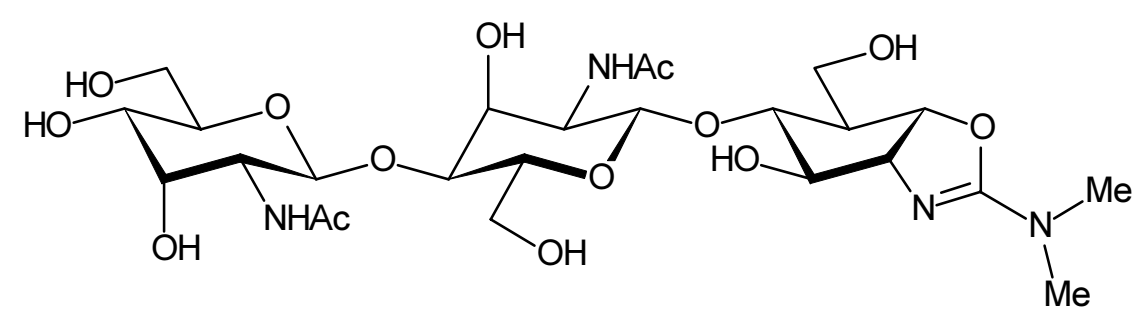

Fig. 1. Pseudotrisaccharide structure of allosamidin, one of the most potent known inhibitors of chitinases

On the other hand, allosamidin did not influence the growth and antibiotic production of the $\beta$-lactam producer filamentous fungi Acremonium chrysogenum [14] and Penicillium chrysogenum [15] (Table I). Importantly, this pseudotrisaccharide hindered significantly the idiophasic breakage of $A$. chrysogenum hyphae [14] as well as the fragmentation and autolysis observable in carbon-depleted $P$. chrysogenum cultures [15]. Allosamidin also inhibited the outgrowth of surviving hyphal fragments in autolysing $P$. chrysogenum cultures when carbon starvation was abolished by the addition of an extra dose of glucose (Figs 2 and 3) [15]. To the best of our knowledge, this was the first presentation of a possible antifungal effect of allosamidin on a filamentous growth form.

Most recent experimental data summarized in Table I clearly indicated that the antifungal effect of allosamidin on autolysing $P$. chrysogenum mycelia was fungistatic rather than fungicidal [16]. To sum it up, allosamidin and its semisynthetic derivatives $[10,17]$ might be effective against filamentous plant, insect or even human pathogenic fungi when cells possessing yeast or yeast-like morphology are thought to play an important role in the invasion of host tissues [18].

\section{Possible glutathione-dependent cellular signalling pathways leading to yeast $\leftrightarrow$ mycelium transitions}

In dimorphic fungi including plant, insect and human pathogenic species, morphological transitions can be provoked by a large constellation of environmental parameters $[18,19]$. Usually, the pathogenicity of these micro-organisms is limited to only one of the morphological forms, and yeast $\leftrightarrow$ mycelium morphological switches 
are likely to play a crucially important role in the pathogenesis of fungal infections [18, 19].

Table I

Morphological and physiological effects of allosamidin on autolysing Penicillium chrysogenum cultures $[15,16]$

\begin{tabular}{|c|c|}
\hline Characteristic & Effect of allosamidin ${ }^{1}$ \\
\hline Autolytic loss of biomass & decreases \\
\hline Number of hyphal elements & increases \\
\hline Chitin content of the walls & increases \\
\hline Release of chitinolytic enzymes & does not influence \\
\hline Vitality estimated by viable cell counts & does not influence \\
\hline $\begin{array}{l}\text { Vitality tested by transferring allosamidin- } \\
\text { treated mycelia into allosamidin-free } \\
\text { culture media (gains in cell dry weights } \\
\text { and outgrowth frequencies) }\end{array}$ & does not influence \\
\hline $\begin{array}{l}\text { Intracellular glutathione, glutathione } \\
\text { disulphide levels and glutathione/ } \\
\text { glutathione disulphide redox balances }\end{array}$ & does not influence \\
\hline Outgrowth after glucose supplementation & inhibits \\
\hline $\begin{array}{l}\text { Glucose utilisation rates in allosamidin- } \\
\text { treated cultures after glucose re-addition }\end{array}$ & reduces \\
\hline $\begin{array}{l}\text { Acidification rates in allosamidin-treated } \\
\text { cultures after glucose re-addition }\end{array}$ & reduces \\
\hline $\begin{array}{l}\text { Utilisation of intracellular glutathione } \\
\text { reserves after carbon supplementation }\end{array}$ & reduces \\
\hline
\end{tabular}

${ }^{1}$ Changes were recorded in the presence of $9.6 \mu \mathrm{M}$ allosamidin between 115 and $167 \mathrm{~h}$ incubation times (autolytic and cryptic growth phases). Allosamidin was added at $35 \mathrm{~h}$ in the deceleration phase of growth. An extra $51 \mathrm{mM}$ glucose was added to selected cultures at $115 \mathrm{~h}$ of incubation.

Remarkably, changes in the intracellular glutathione concentrations and glutathione/glutathione disulphide redox balances are also provoked by versatile environmental factors [20-22]. It is reasonable that the actual redox state of the cellular thiol-disulphide buffer systems will modulate the intracellular protein thiol levels and, hence, the biological activity of specific proteins involved in the regulation of dimorphic switches [23-25]. 


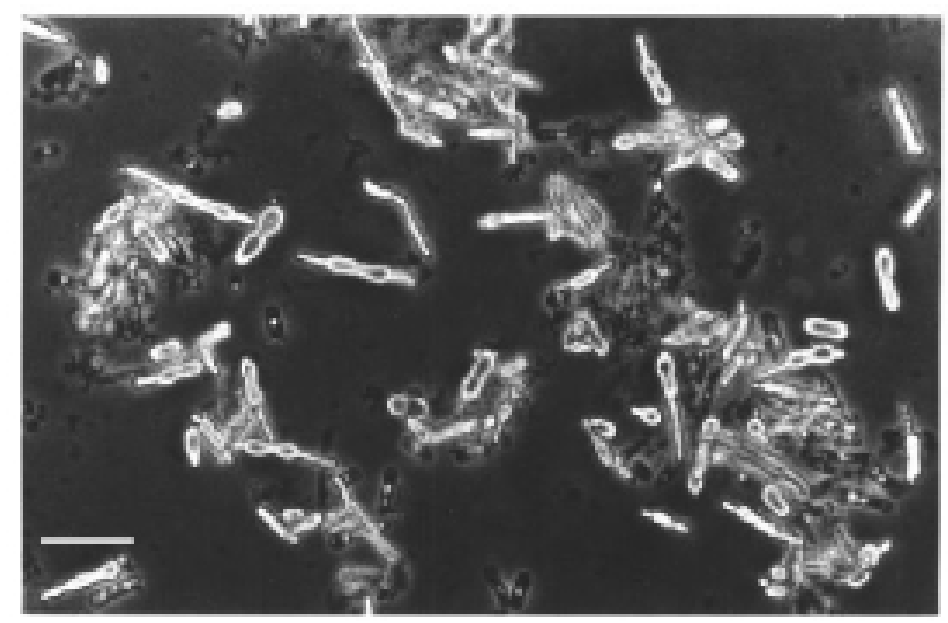

Fig. 2. Outgrowing hyphae in $P$. chrysogenum cultures $(160 \mathrm{~h})$ supplied with $70 \mathrm{mM}$ extra glucose at $115 \mathrm{~h}$ fermentation time. Bar $=40 \mu \mathrm{m}$. Reproduced with permission from [15]. (c) University of Potsdam

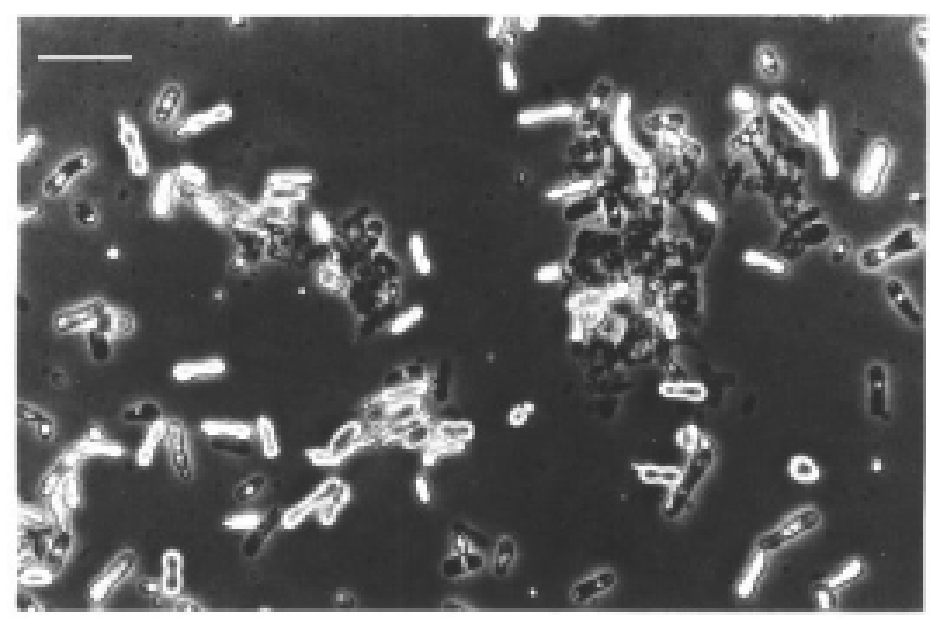

Fig. 3. A P. chrysogenum culture $(160 \mathrm{~h})$ supplemented with $9.6 \mu \mathrm{M}$ allosamidin ( $35 \mathrm{~h}$ fermentation time) and $70 \mathrm{mM}$ glucose (115 h fermentation time). Bar $=40 \mu \mathrm{m}$. Reproduced with permission from [15]. (c) University of Potsdam. 
More recently, diamide, a widely used chemical to disturb the glutathione/glutathione disulphide redox status of the cells by oxidizing glutathione to glutathione disulphide instantaneously and stoichiometrically [26, 27], was shown to have pleiotropic effects on the gene expression profile of $S$. cerevisiae [28]. In addition to protein unfolding and the generation of oxidative stress, diamide was likely to affect disadvantageously the secretion and assemble of cell wall constituents due to improper disulphide bond formation in the endoplasmic reticulum [28]. Changes in the thiol redox status of the cells may therefore have a direct effect on the cell wall structure, which should, of course, result in changes in the observed cell morphology as well. Obviously, any successful attempt to influence or disturb dimorphic transitions via affecting the glutathione metabolism of fungi would attract a great deal of interest from people involved in the development of new antifungal drugs.

The glutathione metabolisms of Aureobasidium pullulans cells possessing either yeast or mycelial morphology has been studied and compared by us [29]. This microorganism is a weak plant pathogenic fungus normally inhabiting the surface of living or senescing leaves exploiting the more readily utilisable nutrients $[18,30]$. Importantly, the cell morphology observed in A. pullulans cultures can be influenced by changing solely the inoculum size [31, 32], which makes this micro-organism an ideal model for the investigation of the physiological background of dimorphic transitions.

In accordance with previous experimental data obtained in Candida albicans cultures [23-25], significantly higher specific glutathione concentrations were found in

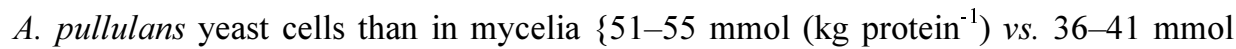
$\left.\left(\mathrm{kg} \operatorname{protein}^{-1}\right)\right\}$ [29]. Surprisingly, there was no significant difference between the glutathione/glutathione disulphide redox status of the cells with either yeast or mycelial morphology.

These experimental data challenge the hypothesis that changes in cellular glutathione/glutathione disulphide redox balances would be involved in the initiation of dimorphic morphological transitions. Although some morphology-dependent differences were recorded in the specific activities of some glutathione metabolic enzymes (e.g. glutathione reductase, $\gamma$-glutamyltranspeptidase) they were not satisfactory to explain the observed alterations in the intracellular glutathione levels. Moreover, in some cases the specific activities differed more significantly in cells sharing the same morphology but separated from pure or mixed morphology cultures than those found in yeast cells and hyphae of a mixed morphology culture [29].

According to these data, the hypothesized effect of intracellular glutathione levels and glutathione metabolic enzymes on the observed cell morphology needs further verification. Taking into consideration of other components of the intracellular thiol pool including cysteine/cystine $[33,34]$ would give us a more reliable overview 
on the role that reduced thiols and thiol buffer systems may play in the initiation and signal transduction events of dimorphic transitions.

\section{Small-size antifungal proteins secreted by fungi}

Small molecular mass (about $\mathrm{M}_{\mathrm{r}}=6000$ ) cysteine-rich antifungal peptides have been shown to be secreted by Aspergillus giganteus [35-38], P. chrysogenum [39], Aspergillus niger [40] and Penicillium nalgiovense [41]. It is remarkable that the $A$. niger antifungal protein shares some common sequential and structural motifs with antifungal proteins of plant origin [40], including Arabidopsis thaliana [42] and Sinapis alba [43]. Although the mechanism of action of fungal proteins has remained to be elucidated the permeabilisation of fungal cell membranes by the analogous plant proteins, defensins and thionins are well-characterized [44, 45]. The cytotoxicity of fungal proteins may also involve interaction with the phospholipid components of the cell membranes [38, 41].

As far as the inhibition spectrum is concerned, the antifungal protein of $A$. giganticus inhibited the growth of Trichoderma koningii $(\mathrm{MIC}=6 \mu \mathrm{M})$, Fusarium oxysporum $(\mathrm{MIC}=7-25 \mu \mathrm{M})$, Penicillium purpurogenum $(\mathrm{MIC}=10 \mu \mathrm{M})$ and Trichoderma harzianum $(\mathrm{MIC}=127 \mu \mathrm{M})$ [38]. This protein did not influence the growth of yeasts including C. albicans, S. cerevisiae, Saccharomyces exiguus, Rhodotorula mucilaginosa and Pichia membranaefaciens and was ineffective against $A$. niger, $P$. chrysogenum and $A$. giganteus, i.e. the producing micro-organism itself. The antifungal protein of $P$. chrysogenum was effective against $A$. niger [39] and $P$. nalgiovense exhibited antagonistic activity against a range of filamentous fungi [40]. It is worth noting that the antifungal protein of $A$. niger (Fig. 4) was active against the yeasts $S$. cerevisiae $(\mathrm{MIC}=8 \mu \mathrm{M})$ and $C$. albicans $(\mathrm{MIC}=8-15 \mu \mathrm{M})$ in addition to numerous filamentous species including Aspergillus flavus, A. fumigatus, $F$. oxysporum, Fusarium solani and Trichosporon beigelii (MIC $=4-15 \mu \mathrm{M})$. Interestingly, no literature data on the possible cytotoxic effects of these antifungal proteins on human or animal cell lines and model organisms have been published thus far but the application of the $P$. nalgiovense protein for biopreservation purposes is being considered [41]. 
Fig. 4. Chemical structure of the small-size antifungal protein of Aspergillus giganteus [35]. Solid lines indicate the positions of disulphide bridges

Regarding that the inhibitory activity and spectrum of antifungal proteins are versatile even in case of closely related species it seems to be definitely worth isolating and testing the antifungal activity of further small-size proteins of this kind. A joint screening program is now in progress in our laboratories.

Acknowledgements: One of us (T.P.) received an OTKA postdoctoral fellowship (grant reference number D34568) and the Hungarian Ministry of Education granted a Széchenyi Scholarship for Professors to I.P., which are greatly acknowledged. These projects are supported financially by the OTKA (grant reference numbers T025174, T032106 and T034315).

\section{References}

1. Ghannoum, M.A., Rice, L.B.: Antifungal agents: mode of action, mechanisms of resistance, and correlation of these mechanisms with bacterial resistance. Clin Microbiol Rev 12, 501 (1999).

2. White, T.C., Marr, K.A., Bowden, R.A.: Clinical, cellular, and molecular factors that contribute to antifungal drug resistance. Clin Microbiol Rev 11, 382 (1998).

3. Walsh, T.J., Viviani, M.A., Arathoon, E., Chiou, C., Ghannoum, M., Groll, A.H., Odds, F.C.: New targets and delivery systems for antifungal therapy. Med. Mycol. 38, 335 (2000).

4. Majoros, L., Kardos, G., Pócsi, I., Szabó, B.: Distribution and susceptibility of Candida species isolated in the Medical University of Debrecen. Acta Microbiol. Immunol. Hung., submitted for publication 
5. Nguyen, M.H., Peacock, J.E., Morris, A.J., Tanner, D.C., Nguyen, M.L., Snydman, D.R., Wagener, M.M., Rinaldi, M.G., Yu, V.L.: The changing face of candidemia: emergence of non-Candida albicans species and antifungal resistance. Am J Med 100, 617 (1996).

6. Gooday, G.W., Zhu, W.-Y., O'Donnell, R.W.: What are the roles of chitinases in the growing fungus? FEMS Microbiol Lett 100, 387 (1992).

7. Gooday, G.W.: The many uses of chitinases in nature. Chitin Chitosan Res 3, 233 (1997).

8. Dickinson, K., Keer, V., Hitchcock, C.A., Adams, D.J.: Chitinase activity from Candida albicans and its inhibition by allosamidin, J Gen Microbiol 135, 1417 (1989).

9. Horsch, M., Mayer, C., Sennhauser, U., Rast D.M.: $\beta$-N-Acetylhexosaminidase: A target for the design of antifungal agents. Pharmacol Ther 76, 187 (1997).

10. Rast, D.M., Merz, R.A., Jeanguenat, A., Mösinger, E.: Enzymes of chitin metabolism for the design of antifungals. In Peter, M.G., Domard, A., Muzzarelli, R.A.A. (eds): Advances in Chitin Science, Vol. 4, University of Potsdam, Potsdam. 2000. pp. 479.

11. Cabib, E., Silverman, S.J., Shaw, J.A.: Chitinase and chitin synthase 1: counterbalancing activities in cell separation of Saccharomyces cerevisiae. J Gen Microbiol 138, 97 (1992).

12. Izumida, H., Nishijima, M., Takadera, T., Nomoto, A.M., Sano, H.: The effect of chitinase inhibitors, cyclo(Arg-Pro) against cell separation of Saccharomyces cerevisiae and the morphological change of Candida albicans. J Antibiot 49, 829 (1995).

13. Takaya, N., Yamazaki, D., Horiuchi, H., Ohta, A., Takagi, M.: Cloning and characterization of a chitinase-encoding gene (chiA) from Aspergillus nidulans, disruption of which decreases germination frequency and hyphal growth. Biosci Biotechnol Biochem 62, 60 (1998).

14. Sándor, E., Pusztahelyi, T., Karaffa, L., Karányi, Z., Pócsi, I., Biró, S., Szentirmai, A., Pócsi, I.: Allosamidin inhibits the fragmentation of Acremonium chrysogenum but does not influence the cephalosporin-C production of the fungus. FEMS Microbiol Lett 164, 231 (1998).

15. Pócsi, I., Emri, T., Varecza, Z., Sámi, L., Pusztahelyi, T.: Allosamidin inhibits the fragmentation and autolysis of Penicillium chrysogenum. In Peter, M.G., Domard, A., Muzzarelli, R.A.A. (eds): Advances in Chitin Science, Vol. 4, University of Potsdam, Potsdam. 2000. pp. 558.

16. Sámi, L., Pusztahelyi, T., Emri, T., Varecza, Z., Fekete, A., Grallert, Á., Karányi, Zs., Kiss, L., Pócsi, I.: Autolysis and aging of Penicillium chrysogenum cultures under carbon starvation: chitinase production and antifungal effect of allosamidin., J Gen Appl Microbiol (in press)

17. Sakuda, S., Sakurada, M.: Preparation of biotinylated allosamidins with strong chitinase inhibitory activities. Bioorg Med Chem Lett 8, 2987 (1998).

18. Deacon, J.W.: In Modern Mycology, Blackwell Science, Oxford. 1997.

19. Orlowski, M.: Yeast/mycelium dimorphism. In Wessels, J.G.H., Meinhardt, F. (eds): The Mycota I. Growth, Differentiation and Sexuality, Springer-Verlag, Berlin. 1994. pp. 143.

20. Penninckx, M.J., Elskens, M.T.: Metabolism and functions of glutathione in micro-organisms. Adv Microbial Physiol 34, 239 (1993)

21. Emri, T., Pócsi, I., Szentirmai, A.: Changes in the glutathione (GSH) metabolism of Penicillium chrysogenum grown on different nitrogen, sulphur and carbon sources. J Basic Microbiol 38, 3 (1998).

22. Penninckx, M.J.: A short review on the role of glutathione in the response of yeasts to nutritional, environmental, and oxidative stresses. Enzyme Microb Technol 26, 737 (2000).

23. Thomas, D., Klein, K., Manavathu, E., Dimmock, J.R., Mutus, B.: Glutathione levels during thermal induction of the yeast-to-mycelial transition in Candida albicans. FEMS Microbiol Lett 77, 331 (1991). 
24. Manavathu, E., Duncan, C., Porte, Q., Gunasekaran, M.: Inhibition of yeast-to mycelium conversion of Candida albicans by conjugated styryl ketones. Mycopathologia 135, 79-83 (1996).

25. Manavathu, M., Gunasekaran, S., Porte, Q., Manavathu, E., Gunasekaran, M.: Changes in glutathione metabolic enzymes during yeast-to-mycelium conversion of Candida albicans. Can J Microbiol 42, 76 (1996).

26. Emri, T., Pócsi, I., Szentirmai, A.: Glutathione metabolism and the protection against oxidative stress caused by peroxides in Penicillium chrysogenum. Free Rad Biol Med 23, 809 (1997).

27. Emri, T., Pócsi, I., Szentirmai, A.: Analysis of the oxidative stress response of Penicillium chrysogenum to menadione. Free Rad Res 30, 125 (1999).

28. Gasch, A.P., Spellman, P.T., Kao, C.M., Carmel-Harel, O., Eisen, M.B., Storz, G., Botstein, D., Brown, P.O.: Genomic expression programs in the response of yeast cells to environmental changes. Mol. Biol. Cell 11, 4241 (2000).

29. Jürgensen, C.W., Jacobsen, N.R., Emri, T., Eriksen, S.H., Pócsi, I.: Glutathione metabolism and dimorphism in Aureobasidium pullulans. J Basic Microbiol, in press (2001).

30. Schena, L., Ippolito, A., Zahavi, T., Cohen, L., Nigro, F., Droby, S.: Genetic diversity and biocontrol activity of Aureobasidium pullulans isolates against postharvest rots. Postharvest Biol Technol 17, 189 (1999).

31. Cooper, L.A., Gadd, G.M.: The induction of mycelial development in Aureobasidium pullulans (IMI 45533) by yeast extract. Antonie van Leeuwenhoek 50, 249 (1984).

32. Reeslev, M., Nielsen, J.C., Olsen, J., Jensen, B., Jacobsen, T.: Effect of pH and the initial concentration of yeast extract on regulation of dimorphism and exopolysaccharide formation of Aureobasidium pullulans in batch culture. Mycol Res 95, 220 (1991).

33. Leith, K.M., Hazen, K.C.: Paraquat induced thiol modulation of Histoplasma capsulatum morphogenesis. Mycopathologia 103, 21 (1988).

34. Maresca, B., Kobayashi, G.S.: Dimorphism in Histoplasma capsulatum: a model for the study of cell differentiation in pathogenic fungi. Microbiol Rev 53, 186 (1989).

35. Nakaya, K., Omata, K., Okahashi, I., Nakamura, Y., Kolkenbrock, H., Ulbrich, N.: Amino acid sequence and disulfide bridges of an antifungal protein isolated from Aspergillus giganteus. Eur J Biochem 193, 31 (1990).

36. Wnendt, S., Ulbrich, N., Stahl, U.: Molecular cloning, sequence analysis and expression of the gene encoding an antifungal-protein from Aspergillus giganteus. Curr Genet 25, 519 (1994).

37. Campos-Olivas, R., Bruix, M., Santoro, J., Lacadena, J., Martinez del Pozo, A., Gavilanes, J.G., Rico, M.: NMR solution structure of the antifungal protein from Aspergillus giganteus: evidence for cysteine pairing isomerism. Biochemistry 34, 3009 (1995).

38. Lacadena, J., Martínez del Pozo, A., Gasset, M., Patiño, B., Campos-Olivas, R., Vázquez, C., MartínezRuiz, A., Mancheño, J.M., Oñaderra, M., Gavilanes, J.G.: Characterization of the antifungal protein secreted by the mould Aspergillus giganteus. Arch Biochem Biophys 324, 273 (1995).

39. Marx, F., Haas, H., Reindl, M., Stöffler, G., Lottspeich, F., Redl, B.: Cloning, structural organization and regulation of expression of the Penicillium chrysogenum paf gene encoding an abundantly secreted protein with antifungal activity. Gene 167, 167 (1995).

40. Lee, D.G., Shin, S.Y., Maeng, C.-Y., Jin, Z.Z., Kim, K.L., Hahm, K.-S.: Isolation and characterisation of a novel antifungal peptide from Aspergillus niger. Biochem Biophys Res Commun 263, 646 (1999). 
41. Geisen, R.: P. nalgiovense carries a gene which is homologous to the paf gene of P. chrysogenum which codes for an antifungal peptide. Int J Food Microbiol 62, 95 (2000).

42. Hu, X., Reddy, A.S.: Cloning and expression of a PR5-like protein from Arabidopsis: inhibition of fungal growth by bacterially expressed protein. Plant Mol Biol 34, 949 (1997).

43. Neumann, G.M., Condron, R., Polya, G.M.: Purification and mass spectrometry-based sequencing of yellow mustard (Sinapis alba L.) $6 \mathrm{kDa}$ proteins. Identification as antifungal proteins. Int J Pept Protein Res 47, 437 (1996).

44. Thevissen, K., Ghazi, A., De Samblanx, G.W., Brownlee, C., Osborn, R.W., Broekaert, W.F.: Fungal membrane responses induced by plant defensins and thionins. J Biol Chem 271, 15018 (1996).

45. Thevissen, K., Terras, F.R., Broekaert, W.F.: Permeabilization of fungal membranes by plant defensins inhibits fungal growth. Appl Environ Microbiol 65, 5451 (1999). 